\title{
Water and Thermal Properties Characterized in Phases of Wheat Flour Dough during Thawing and Baking Conditions
}

\author{
Sander Jonathan Pérez ${ }^{1,2}$, Cinthia Carola Rojas ${ }^{1}$, Ann-Charlotte Eliasson², Malin Elisabet Sjöö ${ }^{2}$ \\ ${ }^{1}$ Food and Natural Products Center, San Simon University, Cochabamba, Bolivia \\ ${ }^{2}$ Department of Food Technology, Engineering and Nutrition, Faculty of Engineering LTH, Lund University, Lund, \\ Sweden \\ Email: sander.perez@food.lth.se
}

\begin{abstract}
Phase separation of dough is based on the thermodynamic incompatibility of its components. The studies on phase-separated systems allow to model, understand, and develop foods. Model dough systems made with water and wheat flour were disassembled into their main structural phases, i.e. liquid, gel, gluten and starch phases, by ultracentrifugation, and further characterized with differential scanning calorimetry (DSC) and microscopy. The study of phase separation, water properties and thermal transitions in phases showed that wheat flour doughs are mainly characterized by the volume fractions of liquid, gel and gluten. The different samples of flours were highly affected by flour combinations. The freezable water (FW) of each separated phase influenced the water properties of the whole dough. The FW is further related to starch thermal behaviour of dough systems at baking temperatures. The methods used here were therefore found relevant from a baking perspective for initial characterizing of flours and dough.
\end{abstract}

Keywords: Ultracentrifugation, dough composition, freezable water, macroscopic separation

\section{Introduction}

The study of food structures and their properties is complicated due to system complexity [1]. Information about the structural hierarchy, possible state, and potential behaviour of food systems can be attained by the thermodynamic incompatibility of biopolymers. This incompatibility can determine the structure, properties and heterophase nature of complex food systems. Consequently, phaseseparated systems allow us to further model, understand, improve and develop novel foods [1]. In order to understand dough development and its implication in breadmaking, Larsson and Eliasson $[2,3]$ used ultracentrifugation to study the phase separation properties of dough showing that ultracentrifugation provides a simple tool for studying the two aqueous phases present in wheat flour dough. The advantage of this technique is based on the fact that the individual phases could be studied without disturbing the phases of the composite dough. Moreover, it was stated that the study of phase separation properties provided information to consider for the evaluation and interpretation of the dough structure formation and properties.

To illustrate this approach, dough, as well as other multicomponent food systems, has a structural hierarchy composed of four levels: submolecular, molecular, supermolecular and macroscopic. The macro scale study of dough is limited to the observation of physical events, like water and thermal properties $[4,5]$. Additionally, dough is accepted to be comprised of two continuous aqueous phases, the liquid phase and the gluten phase, also described as water-swollen protein [6], which form a unique viscoelastic system when being moistened and kneaded. It is widely accepted by cereal scientists that the viscosity development is mainly due to the water-binding capacity of flour components along with the microstructural build-up and breakdown processes that take place within the system during and after being kneaded, when part of the water distributes between the components, and the remainder forms the continuous liquid phase containing soluble components and dispersed starch granules [7,8]. Both thermodynamic and kinetic factors contribute to the competition for water between the components $[1$, 8]. The water properties, including the amount, physical state, location, and interaction with the microstructure, influence the thermal behaviour of dough, and in turn the final quality of bread. This has further relevance in frozen dough systems, where water distribution during freezing and thawing 
affects dough and final bread quality [9]. Using DSC is an effective tool to classify and study water properties for analysis during freezing and thawing. Upon freezing, the ice formation divides the water into freezable water $(\mathrm{FW})$ and unfreezable water $(\mathrm{UFW})$, where the $\mathrm{FW}$ is assumed to be the free water at room temperature [7, 10]. Under this approach the UFW content could be divided into so called bound water $(\mathrm{BW})$ and water in a glassy state.

The purpose of this study was to shed light on the potential of phase separation to investigate dough structure by using ultracentrifugation and a focus on the phase separation, water distribution and thermal properties of each phase to better understand the composite dough system. The aim was to further provide a tool for characterization of macroscopic behaviour combined with DSC analysis for evaluating relevant thermal events during the baking process. Different wheat flours were used to evaluate the method.

\section{Materials and Methods}

\subsection{Material}

Three commercial wheat flours were used in this study, a Swedish wheat flour (F1) (Bagarn's bästa, Lantmännen Food R\&D, Malmö, Sweden), a Bolivian wheat flour (F2) (FAMOSA, Santa Cruz, Bolivia) and a Bolivian wheat flour obtained from a marketplace in Cochabamba-Bolivia (F3).

\subsection{Dough Preparation (Mixing)}

Dough mixing was performed using a kitchen mixer (KitchenAid, St. Joseph, Michigan, USA, Model Artisan KSM 150) at speed 2 for 5 minutes at room temperature. In the present study, the water content of $50 \%(\mathrm{wb})$ was used based on a previously estimated optimum to obtain a fully developed gluten phase in wheat flour dough [2].

\subsection{Ultracentrifugation}

The phase separation properties of wheat flour doughs were performed by ultracentrifugation. Doughs of a corresponding water content of $50 \%(\mathrm{wb})$ were transferred into ultracentrifuge tubes up to a weight of $10 \mathrm{~g}$. The samples were subjected to ultracentrifugation (Optima L-90K ultracentrifuge with SW41 Ti rotor, Beckman Coulter, USA) at 24,000 rpm (corresponding to $100,000 \mathrm{x}$ g) for $1 \mathrm{~h}$. The volume fractions $(\mathrm{VF}, \%)$ of the separated phases were determined by using the method described by Larson and Eliasson (1996) with an accuracy of $\pm 6 \%$; [2]. The test tubes had an internal diameter of $8.5 \mathrm{~mm}$ and a height of $71 \mathrm{~mm}$.

\subsection{Differential Scanning Calorimetry}

Differential scanning calorimetry (DSC) curves of the different doughs and separated phases were recorded and analysed with a Seiko 6200 DSC (Seiko instruments Inc., Shizuoka, Japan) calibrated with indium $\left(\mathrm{Mp}=156.6{ }^{\circ} \mathrm{C}\right)$, and equipped with a cooling device immersion cooler (Haake, EK90/SII, Thermo Fisher Scientific, MA, USA) and EXSTAR6000 Thermal analysis system. At least triplicate samples were analysed for each dough and each separated phase. The samples, $7 \mathrm{mg}$, were rapidly transferred into aluminium pans (TA instruments, New Castle, Delaware, USA), weighed on a C-30 Microbalance (CAHN Instruments Inc., California, USA) and hermetically sealed. With the use of an empty pan as reference, the sample was cooled to $-50{ }^{\circ} \mathrm{C}$ at a rate of $10{ }^{\circ} \mathrm{C} / \mathrm{min}$, and equilibrated until the base lined was stable. The temperature was then linearly increased at a scanning rate of $10{ }^{\circ} \mathrm{C} / \mathrm{min}$ from $-50{ }^{\circ} \mathrm{C}$ to $150{ }^{\circ} \mathrm{C}$. The parameters obtained from DSC curves included transition enthalpy $(\Delta \mathrm{H})$, onset $\left(\mathrm{T}_{\mathrm{o}}\right)$, peak $\left(\mathrm{T}_{\mathrm{p}}\right)$, and final $\left(\mathrm{T}_{\mathrm{f}}\right)$ temperatures, and temperature range $(\Delta \mathrm{T})$ for water properties, i.e. ice melting, and thermal properties during baking and higher temperatures (Fig. 1). 


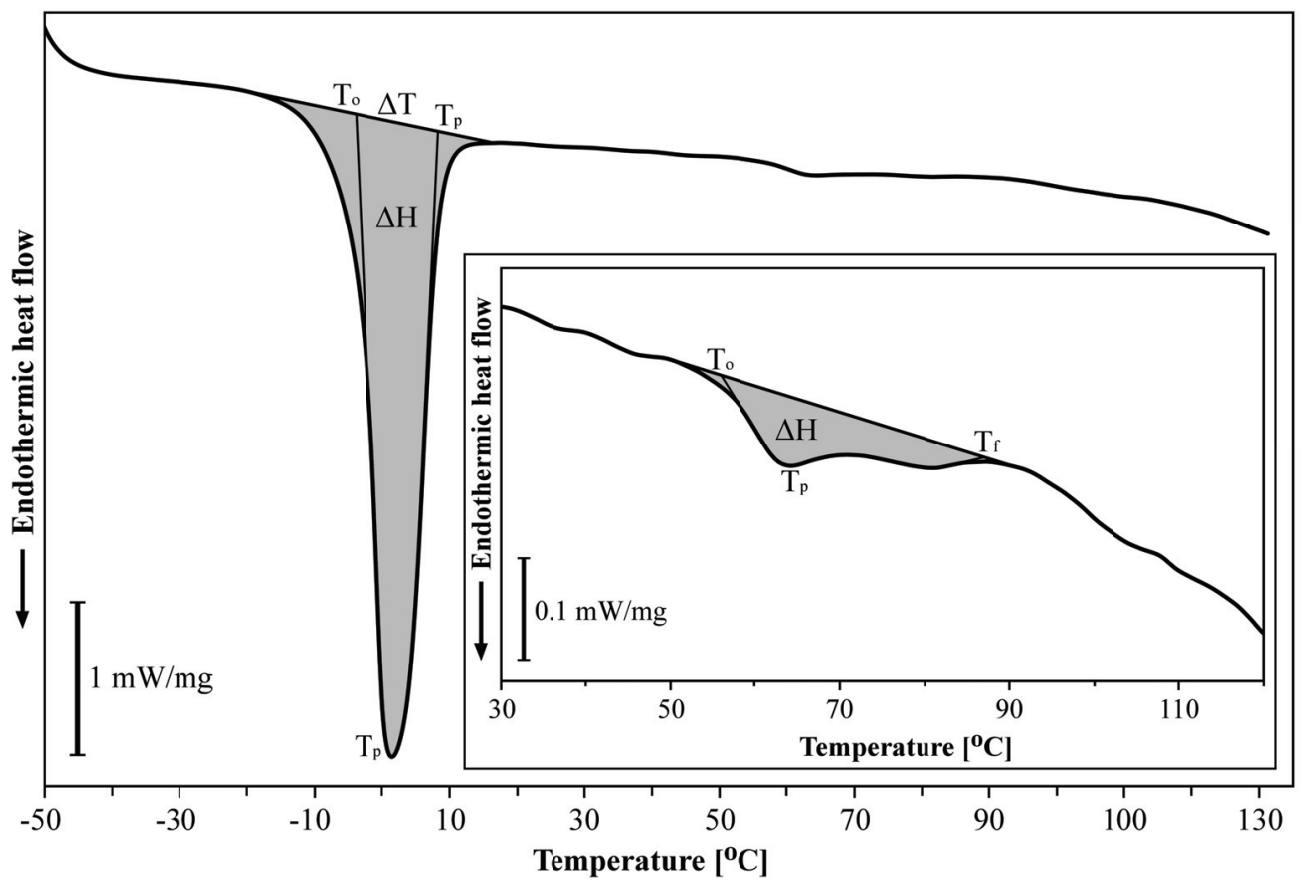

Figure 1. Typical DSC thermograms at ice melting, baking and higher temperatures. Examples of DSC thermograms showing ice melting enthalpy $(\Delta \mathrm{H})$, onset $\left(\mathrm{T}_{\mathrm{o}}\right)$, peak $\left(\mathrm{T}_{\mathrm{p}}\right)$, and final $\left(\mathrm{T}_{\mathrm{f}}\right)$ temperature, melting range $(\Delta \mathrm{T})$, and starch gelatinization enthalpy $(\Delta \mathrm{H})$, onset $\left(\mathrm{T}_{\mathrm{o}}\right)$, peak $\left(\mathrm{T}_{\mathrm{p}}\right)$ and final $\left(\mathrm{T}_{\mathrm{f}}\right)$ temperature. The endothermic heat flow is indicated as scale factors next to the $\mathrm{Y}$ axis of each figure.

\subsection{Water Properties}

DSC was used to study water properties in dough and separated phases, and to distinguish between water content, freezable water and unfreezable water [10]. The water content (W, \%) of each dough and each separated phase was determined by puncturing the pan after DSC analysis and drying at $105{ }^{\circ} \mathrm{C}$ for $24 \mathrm{~h}$. The endothermic peak around $0{ }^{\circ} \mathrm{C}$ (Fig. 1) corresponded to ice melting, and the base line shift was used to calculate the water related parameters. The enthalpy $\left(\Delta \mathrm{H}_{\mathrm{fw}}\right)$ was used to calculate the freezable water content (FW, \%) using Eq. 1.

$$
\mathrm{FW}=\left(\Delta \mathrm{H}_{\mathrm{fw}} / \Delta \mathrm{H}_{\mathrm{f}}\right) \times 100 \%
$$

$\Delta \mathrm{H}_{\mathrm{f}}$ is the latent heat of fusion of ice, taken as that of bulk water $(333.5 \mathrm{~J} / \mathrm{g}$ ) $)$. However, after the measurements of the enthalpy of deionized water with the same protocol, the latent heat of fusion of ice was adjusted by the recorded value of $318 \mathrm{~J} / \mathrm{g}$. It was assumed that the amount of free water present in the sample at room temperature is identical to the amount of freezable water determined from the endothermic peak during melting [11]. The measurement of FW should be done during rewarming after a complete freezing process. The content of unfreezable water (UFW, $\mathrm{mg} / \mathrm{mg}$ ), measured as $\mathrm{mg}$ of unfrozen water $\left(\mathrm{H}_{2} \mathrm{O}\right)$ per mg of dry solid, was determined using Eq. 2.

$$
\mathrm{UFW}=(\mathrm{mg} \text { total water } / \mathrm{mg} \text { total dry solid }) \times(1-\mathrm{FW} / 100)
$$

\subsection{Thermal Properties during Baking and Higher Temperatures}

The thermal events at baking and higher temperatures i.e. above $30{ }^{\circ} \mathrm{C}$, in each dough and in separated phases were determined from the corresponding shift of the base line of the DSC' curves (Fig. 1). The enthalpy $(\Delta \mathrm{Hg}, \mathrm{J} / \mathrm{g})$, the onset temperature $\left(\mathrm{T}_{\mathrm{o}},{ }^{\circ} \mathrm{C}\right)$, and the temperature peak $\left(\mathrm{T}_{\mathrm{p}},{ }^{\circ} \mathrm{C}\right)$ were obtained.

\subsection{Microscopy}

The dough and the separated phases were studied using a microscope (Olympus BX50, Tokyo, Japan) 
equipped with a digital camera (DFK 41AF02, Imaging Source, Germany) under a bright field and polarized light.

\subsection{Statistical Analysis}

The data reported was, on average, of three replications and was subjected to analysis of variance and multiple comparisons using MATLAB (version 9.2, The MathWorks, Natick, MA, USA).

\section{Results and Discussion}

\subsection{Dough Preparation}

Each dough system was different and the handling properties observed in the doughs could be caused by structural properties and the water-binding capacity. F1 and F2 behaved similarly during mixing and created smooth and consistent doughs; on the other hand, F3 seemed more viscous, stickier and attached to the bowl surface. The macroscopic behaviour depends on the microstructure and also directly influences the rheological properties [12]. Dough formation involves physical, colloidal and biochemical processes which depend on the mixing, i.e., mixing speed and mixing time, causing dough viscosity to increase to a maximum, and then to fall off. In breadmaking, mixing, water, aeration, and rheology are closely related, because they affect the baking performance and eventually the product quality. The mixing determines the distribution of water among the different components of dough (i.e. gluten phase, starch and non-starch polysaccharides) [13], the addition of air, and the development of the gluten which have a major influence on dough physical properties[14]. In the present study, the water content and the mixing regime were kept constant for all the samples.

\subsection{Phase Separation Properties of Wheat Flour Dough}

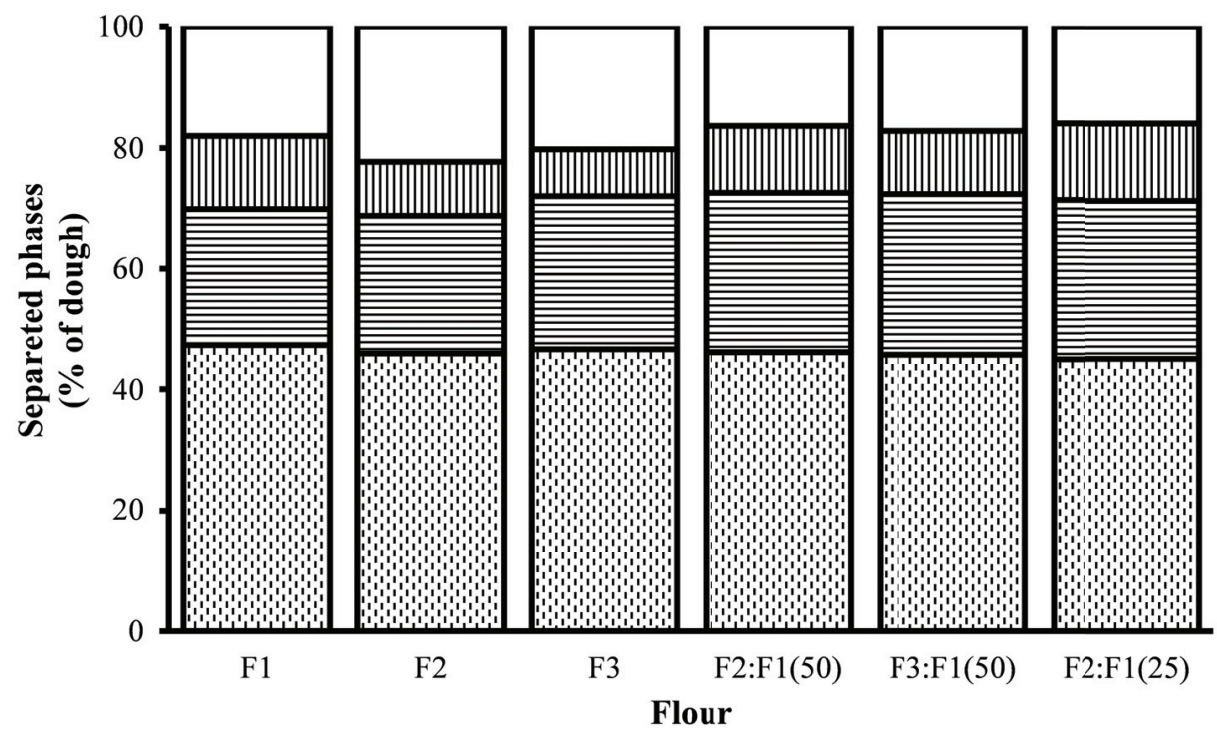

Figure 2. Phase separation behaviour of dough systems made with water and flour. F1, pure Swedish wheat flour; F2, pure Bolivian wheat flour 1; F3, pure Bolivian wheat flour 2; F2:F1(50), 50\% of F2 blended with 50\% of F1; F3:F1(50) 50\% of F3 blended with 50\% of F1; and F2:F1(25), 25\% of F2 blended with 75\% of F1. From top to bottom are: liquid (white), gel (vertical lines), gluten (horizontal lines) and starch (vertical dashes).

A key aspect of dough is the separation of its main components into different phases based on the thermodynamic incompatibility of different biopolymers under certain conditions, and ultracentrifugation is a way to accelerate this phenomenon [13]. In this study the ultracentrifugation of 
wheat flour doughs yielded four sharply separated phases: a liquid phase on the top followed by a gel phase, a gluten phase, and a starch phase (Fig. 2). The liquid phase has been reported to contain lipids and water soluble components such as water extractable pentosans, sugars, salts, and water-soluble proteins [2]. The gel phase was a viscous solution and expected to contain pentosans with high affinity for water [15]. The gluten phase had a rubber-like appearance. The last phase was recognized as starch phase. The same results were obtained by other researchers observing that a sharp separation is dependent on the water content of the dough [2]. In their study doughs at different water contents were subjected to ultracentrifugation and only doughs at high water contents presented sharp separations of four phases; but no phase separation occurred for highly concentrated flour suspensions, which indicated that the development of gluten is enhanced by the availability of water, leading the remaining water to form a second continuous liquid phase with damaged starch and soluble componentis.

F1

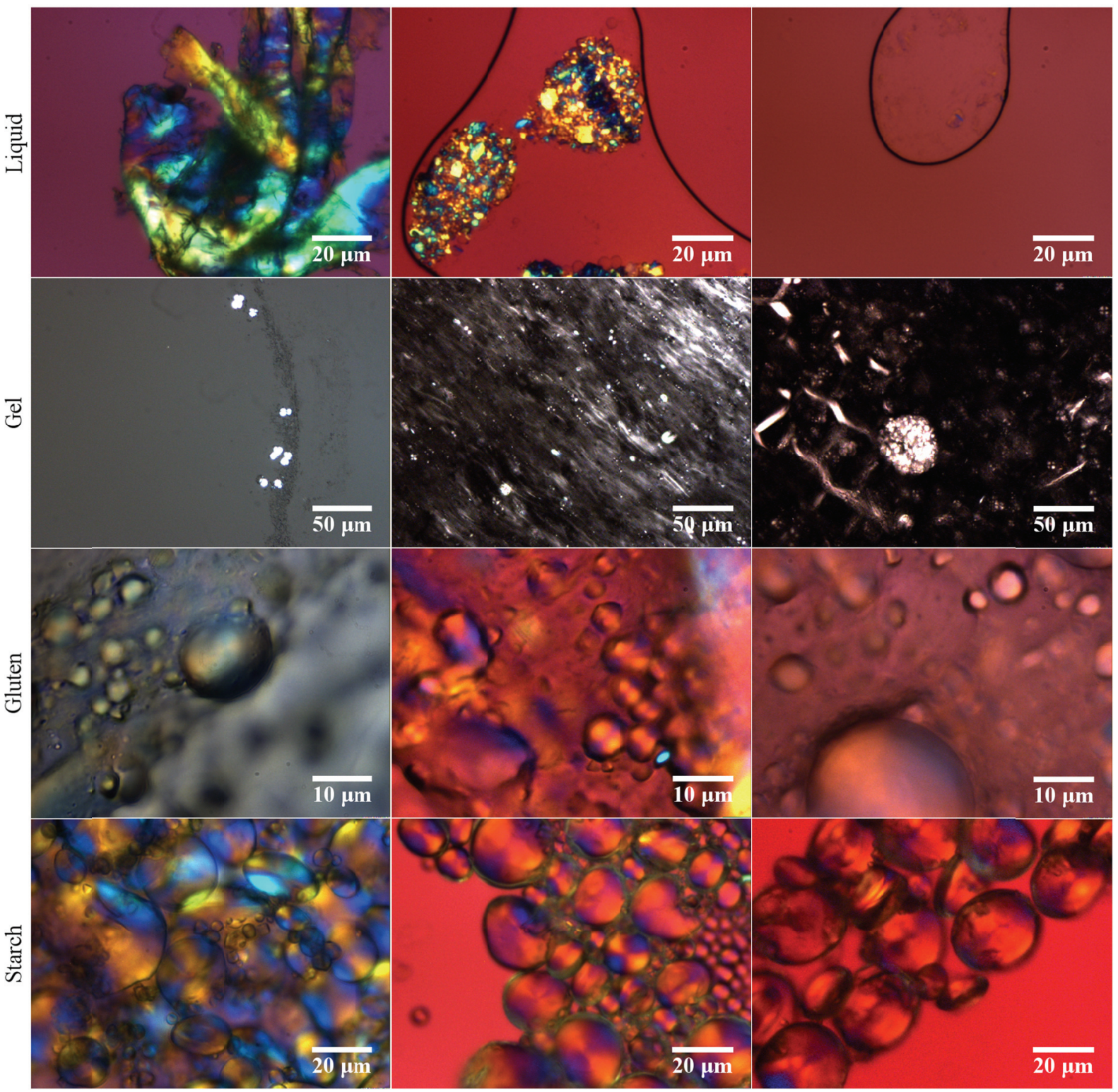

Figure 3. Images of the separated phases. From top to bottom are: liquid, gel, gluten, and starch phases. From left to right are: F1 (Swedish wheat flour), F2 (Bolivian wheat flour 1) and F3 (Bolivian wheat flour 2). 
In this study, each flour dough showed a characteristic phase separation behaviour, i.e.; the volume fractions of the separated phases were different in each dough system. The liquid phase was significantly higher for F2; on the other hand, a larger volume fraction of gel phase characterized F1, and of gluten phase F3 (Fig. 2 and Table 1). This result suggested that the phase separation properties observed could be ascribed to the inner structural differences of the flours. To confirm this, F1 and F2, and F1 and F3 were blended at a level of 50\%. These two blends produced significant changes in all phases' volume fractions, showing that F1 could govern the amount of liquid phase, whereas the gel phase seemed to be more influenced by the presence of flours in each blend (Fig. 2 and Table 1). As for the gluten phase, both blends produced a more gluten phase than pure flours. To further understand the effect of blending on the phase separation behaviour, an additional blend was prepared by blending F1 at $75 \%$ with $25 \%$ of F2. Interestingly enough, the last blend produced gluten and liquid phases similar to those of the previous blends $(\mathrm{p}<0.05)$, and the amount of the gel phase was similar to that of F1. These results suggested that the presence of F1 largely influenced the formation of liquid and gel phases. On the other hand, the effect on the gluten phase could be associated to the reduction of the liquid phase, or be related to the presence of more bran particles in F2 and F3.

The separated phases were studied with a microscope under polarized light (Fig. 3). The image of the liquid phase in F3 is a good example of the general aspect of the liquid phases for all the flours. Nevertheless, the F1 liquid phase contained some single larger bran particles, and in the F2 dough, some agglomerations of small crystals, identified as starch, were found. The main differences between the separated phases of dough from different flours were observed in the gel phases. The F1 gel phase was characterized by a homogenous mass containing a few starch granules. F2 was seen to have a few starch granules and the rest was made of ordered structures, most likely cells damaged during grinding, which looked like bright elongated stripes. F3 mainly contained cell remains with packed starch granules. Under the microscope, the gluten phase looked like a continuous phase containing embedded starch granules along with some bran and large cell remnant particles. The F1 starch phase was different from the F2 and F3 starch phases, since the F1 starch phase contained very small starch granules filling the spaces formed between the largest granules. Among the flours, the F1 starch phase most clearly presented the tri modal particle size distribution of wheat $[16,17]$. Small starch granules have been suggested to have a stabilizing effect on the walls of cells during fermentation [18].

Table 1. Volume fraction $\mathrm{VF}(\%)$ of the separated phases. Volume fraction of the separated phases of dough systems made with water and flour. Mean (M) and standard deviation (SD) of the separated phases. Different letters in the same column indicate significant differences among samples at $\mathrm{P}<0.05$. $\mathrm{N}=3$.

\begin{tabular}{|c|c|c|c|c|c|c|c|c|}
\hline & \multicolumn{2}{|c|}{$\begin{array}{l}\text { Liquid } \\
\mathrm{V}(\%) \\
\end{array}$} & \multicolumn{2}{|c|}{$\begin{array}{l}\text { Gel } \\
\mathrm{V}(\%)\end{array}$} & \multicolumn{2}{|c|}{$\begin{array}{l}\text { Gluten } \\
\mathrm{V}(\%) \\
\end{array}$} & \multicolumn{2}{|c|}{$\begin{array}{l}\text { Starch } \\
\mathrm{V}(\%)\end{array}$} \\
\hline & $\mathrm{M}$ & $\mathrm{SD}$ & $\mathrm{M}$ & $\mathrm{SD}$ & $\mathrm{M}$ & $\mathrm{SD}$ & $\mathrm{M}$ & $\mathrm{SD}$ \\
\hline $\mathrm{F} 1$ & 18.0 & $1.3^{\mathrm{c}}$ & 12.3 & $0.4^{\mathrm{a}}$ & 22.4 & $0.9^{\mathrm{b}}$ & 47.4 & $0.6^{\mathrm{a}}$ \\
\hline $\mathrm{F} 2$ & 22.3 & $0.6^{\mathrm{a}}$ & 9.0 & $0.3^{\mathrm{c}}$ & 22.7 & $0.6^{\mathrm{b}}$ & 46.0 & $0.7^{\mathrm{ab}}$ \\
\hline F3 & 20.2 & $0.6^{\mathrm{b}}$ & 7.9 & $0.2^{\mathrm{d}}$ & 25.2 & $0.8^{\mathrm{a}}$ & 46.7 & $1.2^{\mathrm{ab}}$ \\
\hline F2:F1(50) & 16.4 & $0.5^{\mathrm{cd}}$ & 11.2 & $0.2^{\mathrm{b}}$ & 26.3 & $0.4^{\mathrm{a}}$ & 46.2 & $0.2^{\mathrm{ab}}$ \\
\hline F3:F1(50) & 17.2 & $0.5^{\mathrm{cd}}$ & 10.6 & $0.5^{\mathrm{b}}$ & 26.4 & $0.3^{\mathrm{a}}$ & 45.8 & $0.4^{\mathrm{ab}}$ \\
\hline $\mathrm{F} 2: \mathrm{F} 1(25)$ & 15.9 & $0.2^{\mathrm{d}}$ & 12.8 & $0.3^{\mathrm{a}}$ & 26.2 & $0.4^{\mathrm{a}}$ & 45.1 & $0.6^{\mathrm{b}}$ \\
\hline
\end{tabular}

\subsection{Water Properties of Wheat Flour Doughs and Their Separated Phases}

Figures $4 \mathrm{a}$ and $4 \mathrm{~b}$ show the DSC thermograms of individual flour doughs and blends of $\mathrm{F} 1$ at $50 \%$ and $75 \%$ with F2, and the values of the properties related to water are listed in Table 2 . The values of $\mathrm{W}$ for doughs were slightly lower than $50 \%$, which was expected since some water can be lost by evaporation during mixing. The melting of ice $\left(\mathrm{T}_{\mathrm{o}}\right)$ started at temperatures lower that $0{ }^{\circ} \mathrm{C}(\mathrm{Fig}$. $4 \mathrm{a}-4 \mathrm{~b}$ and Table 2), since supercooling and crystallization of water could take place at lower temperatures or during rewarming. 

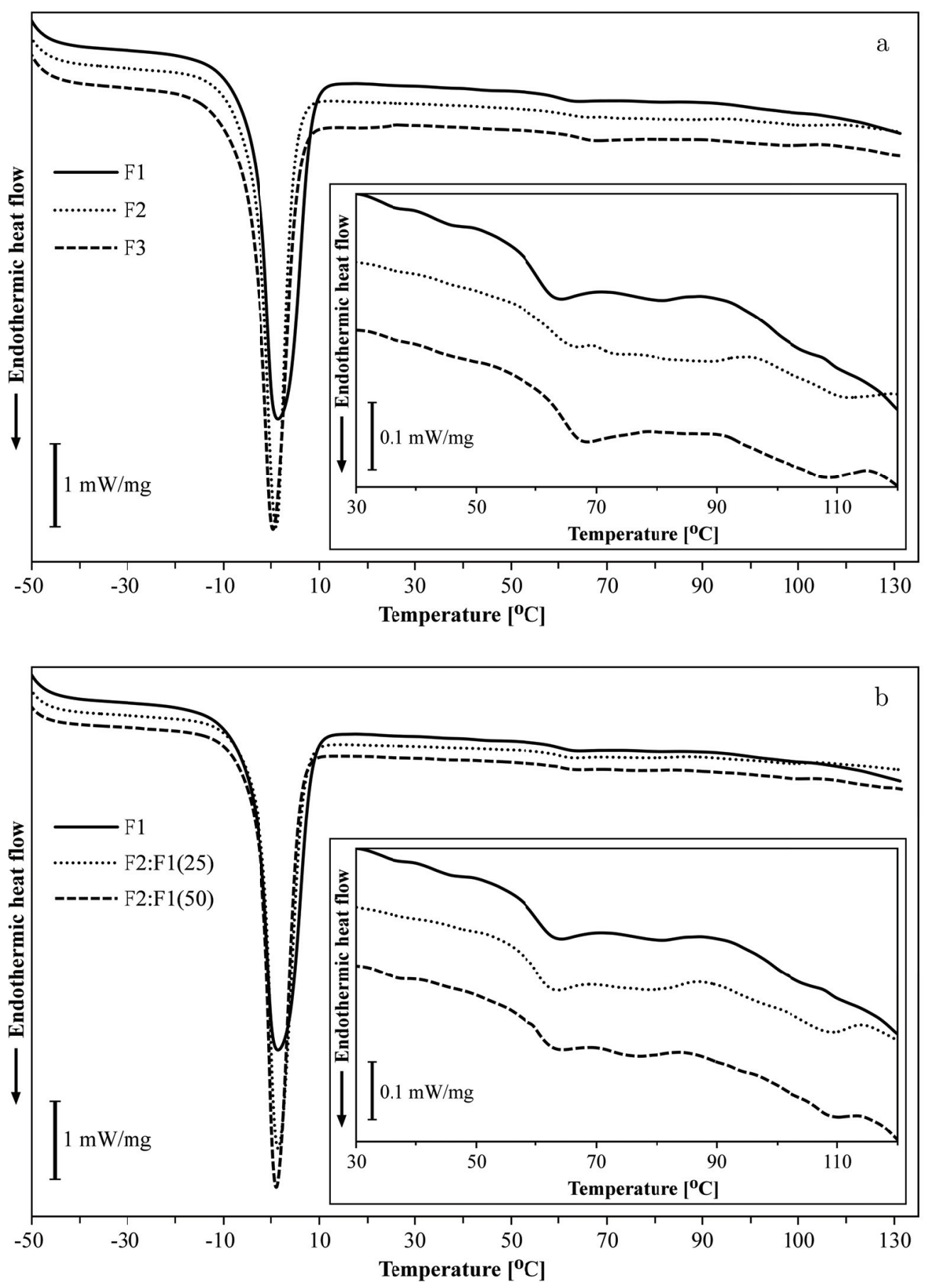

Figure 4. DSC thermograms at ice melting, baking and higher temperatures of dough systems made with water and flour. (a) Swedish wheat flour (F1), Bolivian wheat flour 1 (F2), Bolivian wheat flour 2 (F3); (b) blends of $75 \%$ of $\mathrm{F} 1$ and $25 \%$ of F2 (F2:F1(25)), and $50 \%$ of F1 and 50\% of F2 (F2:F1(50)). 
Table 2. Water properties of wheat flour dough and blended dough. Water content, W(\%); Freezable water content, FW (\%); unfreezable water content, UFW ( $\mathrm{mg} \mathrm{H}_{2} \mathrm{O} / \mathrm{mg}$ dry solid); onset temperature of ice melting, To $\left({ }^{\circ} \mathrm{C}\right)$; peak temperature of ice melting, $\mathrm{Tp}\left({ }^{\circ} \mathrm{C}\right)$; and range temperature of ice melting, $\Delta \mathrm{T}\left({ }^{\circ} \mathrm{C}\right)$ for doughs from individual wheat flours and blends. Different letters in the same column indicate significant differences among samples at $\mathrm{P}<0.05 . \mathrm{N}=3$.

\begin{tabular}{|c|c|c|c|c|c|c|c|c|c|c|c|c|}
\hline & \multicolumn{2}{|c|}{$\begin{array}{l}\text { Water } \\
\text { content } \\
W(\%)\end{array}$} & \multicolumn{2}{|c|}{$\begin{array}{l}\text { Freezable } \\
\text { water } \\
\text { FW }(\%)\end{array}$} & \multicolumn{2}{|c|}{$\begin{array}{l}\text { Unfreezable } \\
\text { water } \\
\text { UFW }(\mathrm{mg} / \mathrm{mg})\end{array}$} & \multicolumn{2}{|c|}{$\begin{array}{l}\text { Onset } \\
\text { temperature } \\
\mathrm{T}_{\mathrm{o}}\left({ }^{\circ} \mathrm{C}\right) \\
\end{array}$} & \multicolumn{2}{|c|}{$\begin{array}{l}\text { Peak } \\
\text { temperature } \\
\mathrm{T}_{\mathrm{p}}\left({ }^{\circ} \mathrm{C}\right) \\
\end{array}$} & \multicolumn{2}{|c|}{$\begin{array}{l}\text { Melting } \\
\text { range } \\
\Delta \mathrm{T}\left({ }^{\circ} \mathrm{C}\right)\end{array}$} \\
\hline & $\mathrm{M}$ & $\mathrm{SD}$ & $\mathrm{M}$ & $\mathrm{SD}$ & $\mathrm{M}$ & $\mathrm{SD}$ & M & $\mathrm{SD}$ & $\mathrm{M}$ & $\mathrm{SD}$ & $\mathrm{M}$ & $\mathrm{SD}$ \\
\hline F1 & 46.75 & $0.75^{\mathrm{a}}$ & 72.36 & $1.42^{\mathrm{a}}$ & 0.24 & $0.01^{\mathrm{b}}$ & -3.27 & $0.05^{\mathrm{b}}$ & 2.3 & $1.51^{\mathrm{a}}$ & 11.47 & $0.85^{\mathrm{a}}$ \\
\hline $\mathrm{F} 2$ & 43.90 & $1.12^{\mathrm{b}}$ & 62.80 & $2.88^{\mathrm{cb}}$ & 0.29 & $0.02^{\mathrm{a}}$ & -3.00 & $0.11^{\mathrm{b}}$ & 1.05 & $0.09^{\mathrm{a}}$ & 8.22 & $0.26^{c}$ \\
\hline F3 & 47.77 & $0.41^{\mathrm{a}}$ & 67.37 & $1.87^{\mathrm{cb}}$ & 0.30 & $0.02^{\mathrm{a}}$ & -3.71 & $0.20^{\mathrm{c}}$ & 0.41 & $0.43^{\mathrm{a}}$ & 9.94 & $0.36^{\mathrm{b}}$ \\
\hline $\mathrm{F} 2: \mathrm{F} 1(25)$ & 47.90 & $0.15^{\mathrm{a}}$ & 70.40 & $0.54^{\mathrm{ab}}$ & 0.27 & $0.01^{\mathrm{ab}}$ & -2.14 & $0.09^{\mathrm{a}}$ & 1.58 & $0.26^{\mathrm{a}}$ & 8.82 & $0.26^{\mathrm{bc}}$ \\
\hline F2:F1(50) & 47.80 & $0.50^{\mathrm{a}}$ & 69.40 & $1.40^{\mathrm{ab}}$ & 0.28 & $0.01^{\mathrm{a}}$ & -2.29 & $0.10^{\mathrm{a}}$ & 1.27 & $0.18^{\mathrm{a}}$ & 8.09 & $0.20^{\mathrm{c}}$ \\
\hline
\end{tabular}

A correlation was seen between $\Delta \mathrm{T}$ and $\mathrm{FW}$, the more $\mathrm{FW}$, the larger $\Delta \mathrm{T}$. According to Ding et al. [7], $\Delta \mathrm{T}$ can be related to the complexity of the melting process during which several relaxation elements of the protein become mobile [11], and there are known complex interactions between water molecules and the studied matrix [7]. FW has been related to the part of water available for colloidal, biochemical, and physicochemical processes during breadmaking. Furthermore, FW is a quality parameter for frozen dough, where a reduced amount of FW is desired to avoid the formation of ice crystals during frozen storage which could result in both the disruption of the gluten network and the injury of yeast cell walls. The amount of freezable water $(\mathrm{FW})$ depended on the flours and their combinations since FW was higher in F1 than in F3 or F2, respectively, and in the blends FW followed the amount of F1 (50\% and $75 \%$ ) (Table 2). The high values of both FW and $\Delta \mathrm{T}$ in F1 (Fig. 4a and Table 2) means that more water is available and that the melting process is more complex in F1 than in F2 or F3. The capillarity/porosity of F1 dough could be the main reason, as its thermograms presented broader and more irregular ice endothermic peaks (Fig. 4a), suggesting a slow crystallization during freezing, which could be due to a lack of heterogeneous nucleation of water enclosed inside dough cavities. However, Berlin et al (1973) demonstrated the additive character of the unfreezable water relative to the different constituents of the material $[19,20]$. Therefore, the water behaviour in dough could be further explained by analysing the water behaviour in the different dough separated phases.

Liquid phase. The analysis of this phase revealed that the quality of the liquid phase is based on not only the amount of volume fraction, but also on the amount of available water (FW); and in turn this availability depends on the solids present. For example, the F1 liquid phase, which had a rather low VF (18\%, Table 1) and water content (W) $(87.40 \%)$ compared to the other flours, had much more freezable water $(\mathrm{FW})(96.86 \%)$ (Table 3$)$. The ice melting range $(\Delta \mathrm{T})$ was narrower, suggesting a more rapid ice melting although this difference was not significant (Table 3). Furthermore, the low amount of UFW suggests that the particles in the F1 liquid phase did not efficiently immobilize water molecules. Microscopy observation showed that the F1 liquid phase was characterized by containing visible larger particles, whereas the F3 liquid phase mainly was characterized by containing more soluble components (Fig. 3), which would agree with its UFW content. Some components of wheat flour, such as pentosans, have a high affinity for water and compete for it during mixing leading to an immobilization of water, which in turn reduces the availability of water for the following processes. Water extractable pentosans are expected to be present in the liquid phase. Wang et al, observed that pentosans are comprised of water extractable pentosans (WEP) and water un-extractable solids (WUS), roughly $25 \%$ and $75 \%$, respectively [21]. Finally, the presence of F1 seemed to dominate the levels of FW and UFW in the liquid phase of the blends. 
Table 3. Water properties of the liquid phase of wheat flour dough and flour blended dough. Different letters in the same column indicate significant differences among samples at $\mathrm{P}<0.05$. $\mathrm{N}=3$.

\begin{tabular}{|c|c|c|c|c|c|c|c|c|c|c|c|c|}
\hline & \multicolumn{2}{|c|}{$\begin{array}{l}\text { Water } \\
\text { content } \\
W(\%)\end{array}$} & \multicolumn{2}{|c|}{$\begin{array}{l}\text { Freezable } \\
\text { water } \\
\text { FW }(\%)\end{array}$} & \multicolumn{2}{|c|}{$\begin{array}{l}\text { Unfreezable } \\
\text { water } \\
\text { UFW }(\mathrm{mg} / \mathrm{mg})\end{array}$} & \multicolumn{2}{|c|}{$\begin{array}{l}\text { Onset } \\
\text { temperature } \\
\mathrm{T}_{\circ}\left({ }^{\circ} \mathrm{C}\right) \\
\end{array}$} & \multicolumn{2}{|c|}{$\begin{array}{l}\text { Peak } \\
\text { temperature } \\
\mathrm{T}_{\mathrm{p}}\left({ }^{\circ} \mathrm{C}\right) \\
\end{array}$} & \multicolumn{2}{|c|}{ Melting range } \\
\hline & M & $\mathrm{SD}$ & M & $\mathrm{SD}$ & M & $\mathrm{SD}$ & $\mathrm{M}$ & SD & M & $\mathrm{SD}$ & M & $\mathrm{SD}$ \\
\hline F1 & 87.40 & $0.04^{\mathrm{c}}$ & 96.86 & $3.56^{\mathrm{a}}$ & 0.22 & $0.25^{\mathrm{b}}$ & -2.61 & $0.29^{\mathrm{a}}$ & 2.10 & $0.94^{\mathrm{ab}}$ & 10.44 & $1.02^{\mathrm{a}}$ \\
\hline $\mathrm{F} 2$ & 88.99 & $0.39^{\mathrm{a}}$ & 89.46 & $5.27^{\mathrm{ab}}$ & 0.85 & $0.41^{\mathrm{ab}}$ & -2.13 & $0.17^{\mathrm{a}}$ & 3.53 & $0.13^{\mathrm{a}}$ & 11.68 & $0.18^{\mathrm{a}}$ \\
\hline F3 & 87.95 & $0.02^{\mathrm{b}}$ & 87.57 & $4.05^{\mathrm{b}}$ & 0.91 & $0.30^{\mathrm{a}}$ & -3.65 & $0.16^{\mathrm{b}}$ & 1.80 & $0.52^{\mathrm{b}}$ & 11.07 & $0.51^{\mathrm{a}}$ \\
\hline $\mathrm{F} 2: \mathrm{F} 1(25)$ & 88.08 & $0.08^{\mathrm{b}}$ & 91.52 & $0.73^{\mathrm{ab}}$ & 0.63 & $0.05^{\mathrm{ab}}$ & -2.32 & $0.07^{\mathrm{a}}$ & 2.12 & $0.12^{\mathrm{ab}}$ & 9.90 & $0.36^{\mathrm{a}}$ \\
\hline $\mathrm{F} 2: \mathrm{F} 1(50)$ & 88.15 & $0.04^{\mathrm{b}}$ & 94.45 & $0.73^{\mathrm{ab}}$ & 0.41 & $0.05^{\mathrm{ab}}$ & -2.48 & $0.08^{\mathrm{a}}$ & 2.04 & $0.37^{\mathrm{ab}}$ & 10.45 & $0.51^{\mathrm{a}}$ \\
\hline
\end{tabular}

Gel phase. The gel phase presented high values of water content (W), freezable water (FW), unfreezable water content (UFW), and melting range $(\Delta \mathrm{T})$. WUS is expected to be present in the gel phases, which are known to have high water affinity. The different liquid and gel phases generally presented the highest values of UFW (Tables 3 and 4), which was expected since pentosans are expected to be present in both phases. The gel phase could be responsible for the melting process in dough and could hold more water during the whole baking process. The main differences between flours observed in the gel phases were that F1 had more W and FW. Furthermore, in the test tube, this phase looked clearer and less dense, and under a microscope was more uniform without extensive visible bran or cell remnants (Fig. 2). The gel phases of the blends did not show a clear influence of F1 nor F2.

Table 4. Water properties of the gel phase of wheat flour dough and flour blended dough. Different letters in the same column indicate significant differences among samples at $\mathrm{P}<0.05$. $\mathrm{N}=3$.

\begin{tabular}{|c|c|c|c|c|c|c|c|c|c|c|c|c|}
\hline & \multicolumn{2}{|c|}{ Water content } & \multicolumn{2}{|c|}{$\begin{array}{l}\text { Freezable } \\
\text { water } \\
\text { FW }(\%)\end{array}$} & \multicolumn{2}{|c|}{$\begin{array}{l}\text { Unfreezable } \\
\text { water } \\
\text { UFW }(\mathrm{mg} / \mathrm{mg})\end{array}$} & \multicolumn{2}{|c|}{$\begin{array}{l}\text { Onset } \\
\text { Temperature } \\
\mathrm{T}_{\mathrm{o}}\left({ }^{\circ} \mathrm{C}\right)\end{array}$} & \multicolumn{2}{|c|}{$\begin{array}{l}\text { Peak } \\
\text { temperature } \\
\mathrm{T}_{\mathrm{p}}\left({ }^{\circ} \mathrm{C}\right)\end{array}$} & \multicolumn{2}{|c|}{ Melting range } \\
\hline & $\mathrm{M}$ & $\mathrm{SD}$ & $\mathrm{M}$ & $\mathrm{SD}$ & $\mathrm{M}$ & $\mathrm{SD}$ & $\mathrm{M}$ & $\mathrm{SD}$ & $\mathrm{M}$ & $\mathrm{SD}$ & $\mathrm{M}$ & SD \\
\hline F1 & 84.13 & $0.20^{\mathrm{ab}}$ & 89.95 & & 0.53 & $0.05^{\mathrm{b}}$ & -2.86 & $0.18^{\mathrm{b}}$ & 2.17 & $0.21^{\mathrm{b}}$ & 12.69 & $0.41^{\mathrm{a}}$ \\
\hline $\mathrm{F} 2$ & 0.26 & $2.67^{\mathrm{bc}}$ & & $3.81^{\mathrm{bc}}$ & 0.5 & $0.09^{\mathrm{b}}$ & -2.73 & $0.13^{\mathrm{b}}$ & 2.58 & 0.58 & & $0.08^{\mathrm{a}}$ \\
\hline F3 & 79.06 & $1.61^{\mathrm{c}}$ & 84.80 & $1.45^{\mathrm{bc}}$ & 0.58 & $0.10^{\mathrm{b}}$ & -4.25 & $0.27^{\mathrm{c}}$ & 1.15 & $0.23^{c}$ & 11.37 & $0.07^{\mathrm{a}}$ \\
\hline $\mathrm{F} 2: \mathrm{F} 1(25)$ & 85.70 & $0.17^{\mathrm{a}}$ & 91.26 & $0.13^{\mathrm{a}}$ & 0.52 & $0.00^{\mathrm{b}}$ & -2.52 & $0.06^{\mathrm{b}}$ & 2.20 & $0.28^{\mathrm{b}}$ & 9.17 & $0.63^{\mathrm{b}}$ \\
\hline F2:F1(50) & 84.24 & $0.89^{\mathrm{ab}}$ & 84.40 & $1.10^{\mathrm{c}}$ & 0.83 & $0.01^{\mathrm{a}}$ & -1.87 & $0.06^{\mathrm{a}}$ & 3.93 & $0.31^{\mathrm{a}}$ & 12.39 & $1.21^{\mathrm{a}}$ \\
\hline
\end{tabular}

Gluten phase. The gluten phases of the different flours and blends were very similar with regard to the properties analysed (Table 5). The gluten phases presented similar values of W, which were higher than $50 \%$ (Table 5). This result agreed with the literature [3] describing the $\mathrm{W}$ in the gluten phase mainly to be related to the mixing time, since long periods of mixing can increase the presence of water in the gluten phase and change properties. The gluten phase of $\mathrm{F} 1$ tended to be higher in $\mathrm{FW}$ and $\Delta \mathrm{T}$ than F2 or F3. Once more, F1 was richer in FW than F2 and F3. The same trend was observed in the previous phases. This behaviour could be due to a different physical accommodation of water inside gluten structure which allowed a recrystallization of water during rewarming, which was confirmed by DSC thermograms of gluten phases (Fig. 5) and by the high value of $\Delta \mathrm{T}$ (Table 5). Finally, it was clear from DSC thermograms (Fig. 5) that F1 and F2 or F3 differed in water behaviour of the gluten phases. This could be related to water holding capacities indicated by the UFW and especially to the gluten structure itself. The broadness of $\Delta \mathrm{T}$ of dough could be associated to the values of $\Delta \mathrm{T}$ in the gluten and gel phases. Microscopy observation showed more presence of bran in the gluten phases of F2 and F3. 
Table 5. Water properties of the gluten phase of wheat flour dough and flour blended dough. Abbreviations are the same as in Table 3. Different letters in the same column indicate significant differences among samples at $\mathrm{P}<0.05$. $\mathrm{N}=3$.

\begin{tabular}{|c|c|c|c|c|c|c|c|c|c|c|c|c|}
\hline & \multicolumn{2}{|c|}{ Water content } & \multicolumn{2}{|c|}{ Freezable water } & \multicolumn{2}{|c|}{$\begin{array}{l}\text { Unfreezable } \\
\text { water } \\
\text { UFW }(\mathrm{mg} / \mathrm{mg})\end{array}$} & \multicolumn{2}{|c|}{$\begin{array}{l}\text { Onset } \\
\text { temperature } \\
\mathrm{T}_{o}\left({ }^{\circ} \mathrm{C}\right)\end{array}$} & \multicolumn{2}{|c|}{$\begin{array}{l}\text { Peak } \\
\text { temperature } \\
\mathrm{T}_{\mathrm{p}}\left({ }^{\circ} \mathrm{C}\right)\end{array}$} & \multicolumn{2}{|c|}{ Melting range } \\
\hline & $\mathrm{M}$ & $\mathrm{SD}$ & $\mathrm{M}$ & $\mathrm{SD}$ & $\mathrm{M}$ & $\mathrm{SD}$ & $\mathrm{M}$ & $\mathrm{SD}$ & M & SD & $\mathrm{M}$ & $\mathrm{SD}$ \\
\hline F1 & 52.89 & $0.71^{\mathrm{a}}$ & 72.36 & $0.75^{\mathrm{a}}$ & 0.31 & $0.01^{\mathrm{b}}$ & -2.48 & $1.83^{\mathrm{a}}$ & 4.68 & $1.28^{\mathrm{a}}$ & 12.92 & $2.22^{\mathrm{a}}$ \\
\hline $\mathrm{F} 2$ & 52.58 & $0.54^{\mathrm{a}}$ & 71.14 & $2.36^{\mathrm{ab}}$ & 0.32 & $0.03^{\mathrm{ab}}$ & -3.52 & $0.56^{\mathrm{a}}$ & 1.18 & $0.26^{\mathrm{b}}$ & 10.42 & $1.59^{\mathrm{ab}}$ \\
\hline F3 & 53.29 & $1.34^{\mathrm{a}}$ & 68.02 & $1.42^{\mathrm{b}}$ & 0.37 & $0.02^{\mathrm{a}}$ & -4.44 & $0.42^{\mathrm{a}}$ & 0.27 & $0.26^{\mathrm{b}}$ & 9.98 & $1.55^{\mathrm{ab}}$ \\
\hline $\mathrm{F} 2: \mathrm{F} 1(25)$ & 51.28 & $0.95^{\mathrm{a}}$ & 71.52 & $1.85^{\mathrm{a}}$ & 0.30 & $0.02^{\mathrm{b}}$ & -2.98 & $0.08^{\mathrm{a}}$ & 1.12 & $0.23^{\mathrm{b}}$ & 8.45 & $0.61^{\mathrm{b}}$ \\
\hline $\mathrm{F} 2: \mathrm{F} 1(50)$ & 51.99 & $0.50^{\mathrm{a}}$ & 74.43 & $0.55^{\mathrm{a}}$ & 0.28 & $0.01^{\mathrm{b}}$ & -3.05 & $0.06^{\mathrm{a}}$ & 0.98 & $0.30^{\mathrm{b}}$ & 9.34 & $0.32^{\mathrm{ab}}$ \\
\hline
\end{tabular}

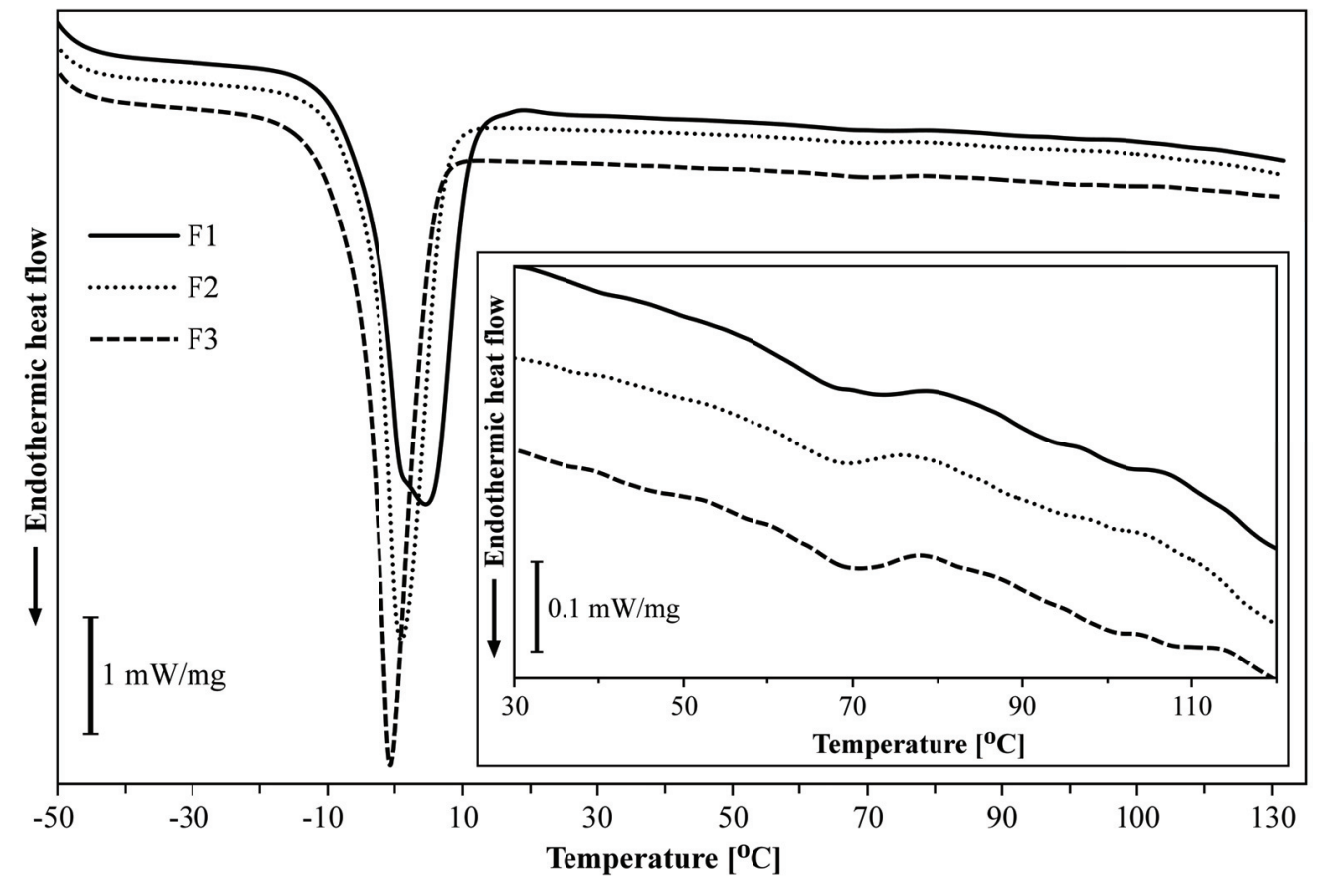

Figure 5. DSC thermograms at ice melting, baking and higher temperatures of gluten phases. Swedish wheat flour (F1), Bolivian wheat flour 1 (F2), Bolivian wheat flour 2 (F3).

Starch phase. Since this phase was the largest one, the effect of the position was also taken into account, i.e. the top and bottom parts were analysed separately (Table 6 and 7). The FW and UFW are related to the solid properties, in this specific case, to the starch granules. In general, the values of the FW were higher at the top part. Furthermore, the W is highly affected by the centrifugal force applied and therefore generally higher in the top part. The analysis of the water properties was considered more relevant in the top part. The starch phase of $\mathrm{F} 1$ presented higher values for $\mathrm{W}$ and $\mathrm{FW}$ in comparison to those of F2 and F3. It seems reasonable to suggest that water was more availiable in the F1 starch phase, and also that the F1 starch phase seemed to have a higher affinity for water or a better distribution of water inside the interstitial alloys formed by the starch granules (Fig. 3). The behaviour of FW in dough (Table 2) seems to follow the behaviour of FW in their respective: starch phases (Table $6)$. This is reasonable since starch is the major component in the dough. 
Table 6. Water properties of the top starch phase of wheat flour dough and flour blended dough. Different letters in the same column indicate significant differences among samples at $\mathrm{P}<0.05$. $\mathrm{N}=3$.

\begin{tabular}{|c|c|c|c|c|c|c|c|c|c|c|c|c|}
\hline & \multicolumn{2}{|c|}{ Water content } & \multicolumn{2}{|c|}{$\begin{array}{l}\text { Freezable } \\
\text { water } \\
\text { FW }(\%) \\
\end{array}$} & \multicolumn{2}{|c|}{$\begin{array}{l}\text { Unfreezable } \\
\text { water } \\
\text { UFW }(\mathrm{mg} / \mathrm{mg})\end{array}$} & \multicolumn{2}{|c|}{$\begin{array}{l}\text { Onset } \\
\text { temperature } \\
\mathrm{T}_{\circ}\left({ }^{\circ} \mathrm{C}\right) \\
\end{array}$} & \multicolumn{2}{|c|}{$\begin{array}{l}\text { Peak } \\
\text { temperature } \\
\mathrm{T}_{\mathrm{p}}\left({ }^{\circ} \mathrm{C}\right)\end{array}$} & \multicolumn{2}{|c|}{ Melting range } \\
\hline & $\mathrm{M}$ & $\mathrm{SD}$ & $\mathrm{M}$ & $\mathrm{SD}$ & M & SD & $\mathrm{M}$ & $\mathrm{SD}$ & $\mathrm{M}$ & SD & $\mathrm{M}$ & $\mathrm{SD}$ \\
\hline $\mathrm{F} 1$ & 30.94 & $2.98^{\mathrm{a}}$ & 37.23 & $1.85^{\mathrm{a}}$ & 0.28 & $0.04^{\mathrm{a}}$ & -2.28 & $0.55^{\mathrm{a}}$ & 2.47 & $1.28^{\mathrm{a}}$ & 10.06 & $0.97^{\mathrm{a}}$ \\
\hline $\mathrm{F} 2$ & 20.83 & $1.09^{c}$ & 8.22 & $3.36^{\mathrm{c}}$ & 0.24 & $0.02^{\mathrm{a}}$ & -1.34 & 0.3 & 0.35 & $0.04^{\mathrm{b}}$ & 4.84 & $0.68^{\mathrm{b}}$ \\
\hline F3 & 23.37 & $0.64^{\mathrm{bc}}$ & 23.98 & $5.74^{\mathrm{b}}$ & 0.23 & $0.02^{\mathrm{a}}$ & -5.03 & $0.95^{\mathrm{b}}$ & 0.84 & $0.26^{\mathrm{ab}}$ & 8.24 & $1.10^{\mathrm{a}}$ \\
\hline $\mathrm{F} 2: \mathrm{F} 1(25)$ & 28.48 & $2.09^{\mathrm{ab}}$ & 33.29 & $4.73^{\mathrm{ab}}$ & 0.27 & $0.05^{\mathrm{a}}$ & -1.42 & $0.38^{\mathrm{a}}$ & 1.75 & $0.84^{\mathrm{ab}}$ & 8.92 & $0.09^{\mathrm{a}}$ \\
\hline F2:F1(50) & 25.65 & $2.54^{\mathrm{abc}}$ & 29.15 & $6.30^{\mathrm{ab}}$ & 0.24 & $0.02^{\mathrm{a}}$ & -1.53 & $0.02^{\mathrm{a}}$ & 0.84 & $0.26^{\mathrm{ab}}$ & 7.71 & $1.77^{\mathrm{ab}}$ \\
\hline
\end{tabular}

Table 7. Water properties of the bottom starch phase of wheat flour dough and flour blended dough. Different letters in the same column indicate significant differences among samples at $\mathrm{P}<0.05$. $\mathrm{N}=3$.

\begin{tabular}{|c|c|c|c|c|c|c|c|c|c|c|c|c|}
\hline & \multicolumn{2}{|c|}{ Water content } & \multicolumn{2}{|c|}{$\begin{array}{l}\text { Freezable } \\
\text { Water } \\
\text { FW(\%) }\end{array}$} & \multicolumn{2}{|c|}{$\begin{array}{l}\text { Unfreezable } \\
\text { water } \\
\text { UFW }(\mathrm{mg} / \mathrm{mg})\end{array}$} & \multicolumn{2}{|c|}{$\begin{array}{l}\text { Onset } \\
\text { temperature } \\
\mathrm{T}_{\mathrm{o}}\left({ }^{\circ} \mathrm{C}\right)\end{array}$} & \multicolumn{2}{|c|}{$\begin{array}{l}\text { Peak } \\
\text { temperature } \\
\mathrm{T}_{\mathrm{p}}\left({ }^{\circ} \mathrm{C}\right) \\
\end{array}$} & \multicolumn{2}{|c|}{$\begin{array}{l}\text { Melting } \\
\text { range } \\
\Delta \mathrm{T}\left({ }^{\circ} \mathrm{C}\right)\end{array}$} \\
\hline & M & SD & $\mathrm{M}$ & SD & M & SD & M & SD & M & SD & $\mathrm{M}$ & SD \\
\hline F1 & 26.11 & $3.03^{\mathrm{a}}$ & 33.10 & $2.55^{\mathrm{a}}$ & 0.24 & $0.04^{\mathrm{ab}}$ & & & 0.60 & $0.12^{\mathrm{a}}$ & 7.50 & $1.50^{\mathrm{a}}$ \\
\hline $\mathrm{F} 2$ & 17.75 & $1.19^{\mathrm{c}}$ & 18.51 & $15.42^{\mathrm{ab}}$ & 0.18 & $0.05^{\mathrm{b}}$ & -6.42 & $7.61^{\mathrm{a}}$ & -1.11 & $2.04^{\mathrm{a}}$ & 9.04 & $6.11^{\mathrm{a}}$ \\
\hline F3 & 18.10 & $0.77^{\mathrm{c}}$ & 9.52 & $5.76^{\mathrm{b}}$ & 0.20 & $0.01^{\mathrm{ab}}$ & -1.32 & $0.35^{\mathrm{a}}$ & 0.43 & $0.00^{\mathrm{a}}$ & 4.81 & $0.54^{\mathrm{a}}$ \\
\hline $\mathrm{F} 2: \mathrm{F} 1(25)$ & 24.77 & $1.56^{\mathrm{ab}}$ & 20.19 & $3.88^{\mathrm{ab}}$ & 0.26 & $0.01^{\mathrm{a}}$ & -1.08 & $0.14^{\mathrm{a}}$ & 0.64 & $0.15^{\mathrm{a}}$ & 5.79 & $0.71^{\mathrm{a}}$ \\
\hline $\mathrm{F} 2: \mathrm{F} 1(50)$ & 21.08 & $0.37^{\mathrm{bc}}$ & 20.93 & $1.58^{\mathrm{ab}}$ & 0.21 & $0.00^{\mathrm{ab}}$ & -1.10 & $0.06^{\mathrm{a}}$ & 0.54 & $0.09^{\mathrm{a}}$ & 5.26 & $0.67^{\mathrm{a}}$ \\
\hline
\end{tabular}

\subsection{Thermal Properties of Wheat Flour Doughs and Their Separated Phases}

Table 8. Thermal properties of the dough of wheat flours and wheat flour blends, gelatinization enthalpy. $\Delta H$ $(\mathrm{J} / \mathrm{g})$; onset temperature of gelatinization, To $\left({ }^{\circ} \mathrm{C}\right)$; peak temperature of gelatinization, $\mathrm{Tp}\left({ }^{\circ} \mathrm{C}\right)$; range temperature of ice melting, $\Delta \mathrm{T}\left({ }^{\circ} \mathrm{C}\right)$. Different letters in the same column indicate significant differences among samples at $\mathrm{P}<0.05 . \mathrm{N}=3$.

\begin{tabular}{|c|c|c|c|c|c|c|c|c|}
\hline & \multicolumn{2}{|c|}{$\begin{array}{l}\text { Gelatinization } \\
\text { enthalpy } \\
\Delta \mathrm{H}(\mathrm{J} / \mathrm{g}) \\
\end{array}$} & \multicolumn{2}{|c|}{$\begin{array}{l}\text { Onset } \\
\text { temperature } \\
\mathrm{T}_{\mathrm{o}}\left({ }^{\circ} \mathrm{C}\right) \\
\end{array}$} & \multicolumn{2}{|c|}{$\begin{array}{l}\text { Peak } \\
\text { temperature } \\
\mathrm{T}_{\mathrm{p}}\left({ }^{\circ} \mathrm{C}\right) \\
\end{array}$} & \multicolumn{2}{|c|}{$\begin{array}{l}\text { Range } \\
\text { temperature } \\
\Delta \mathrm{T}\left({ }^{\circ} \mathrm{C}\right) \\
\end{array}$} \\
\hline & $\mathrm{M}$ & $\mathrm{SD}$ & $\mathrm{M}$ & $\mathrm{SD}$ & $\mathrm{M}$ & $\mathrm{SD}$ & $\mathrm{M}$ & $\mathrm{SD}$ \\
\hline F1 & 6.38 & $0.33^{\mathrm{a}}$ & 56.9 & $0.82^{\mathrm{b}}$ & 64.5 & $0.75^{\mathrm{c}}$ & 28.65 & $0.49^{\mathrm{b}}$ \\
\hline $\mathrm{F} 2$ & 6.76 & $0.75^{\mathrm{a}}$ & 56.63 & $0.47^{\mathrm{b}}$ & 66.84 & $0.09^{\mathrm{b}}$ & 37.45 & $2.62^{\mathrm{a}}$ \\
\hline F3 & 6.44 & $0.83^{\mathrm{a}}$ & 60.6 & $0.1^{\mathrm{a}}$ & 68.77 & $0.61^{\mathrm{a}}$ & 21.37 & $2.44^{\mathrm{c}}$ \\
\hline $\mathrm{F} 2: \mathrm{F} 1(25)$ & 5.52 & $0.11^{\mathrm{a}}$ & 59.44 & $0.5^{\mathrm{a}}$ & 64.46 & $1.02^{\mathrm{c}}$ & 23.91 & $2.22^{\mathrm{bc}}$ \\
\hline $\mathrm{F} 2: \mathrm{F} 1(50)$ & 6.36 & $0.19^{\mathrm{a}}$ & 57.32 & $0.64^{\mathrm{b}}$ & 63.71 & $0.14^{\mathrm{c}}$ & 28.5 & $1.1^{\mathrm{b}}$ \\
\hline
\end{tabular}

Thermal properties of dough systems. The thermal properties of dough samples were measured by using DSC. The thermograms for the different samples shown in Fig 4a and 4b were typical for doughs, which present two endotherms for the gelatinization of starch at approximately $55-85{ }^{\circ} \mathrm{C}$ and one more at above $100^{\circ} \mathrm{C}$ for the melting of the amylose-lipid complex $[22,23]$. Nevertheless, the samples showed different characteristics in their thermal properties, such as the onset and peak temperatures of the gelatinization of starch, where F1 presented the lowest values and F3 the highest (Table 8). Additionally, the temperature range of these gelatinization endotherms presented differences, where F2 had the broadest and largest transition. Donovan (1979) indicated that the amount of water is an important factor affecting the area and onset temperature of the gelatinization endotherms[24]. However, not only the amount of water, but also whether the water can migrate freely or if is it held by gluten or 
another component would influence [22]. This supports the present results, since F1 had the lowest onset and peak temperature and concurrently the highest amount of freezable water. These thermal properties along with the water properties presented above suggest that F1 seems to present the best condition for baking.

Transitions of different components can occur in overlapping temperature ranges. Therefore, the thermal properties of the separated phases were investigated to clarify their separate contributions (Fig. 6 ). The high sensitivity of the equipment and the aid of the first derivative of the DSC curve allowed observation of different small changes in the baseline that could be relevant during baking, up to $95{ }^{\circ} \mathrm{C}$, for the breadmaking quality. Finally, the endotherm for the melting of amylose-lipid complex was not detected in F1 (Table 9).

Table 9. Amylose-lipid complex of dough of wheat flours and wheat flour blends. Melting enthalpy, $\Delta \mathrm{H}(\mathrm{J} / \mathrm{g})$; onset temperature, To $\left({ }^{\circ} \mathrm{C}\right)$; peak temperature, $\mathrm{Tp}\left({ }^{\circ} \mathrm{C}\right)$; range temperature, $\Delta \mathrm{T}\left({ }^{\circ} \mathrm{C}\right)$, n.d. not detected. Different letters in the same column indicate significant differences among samples at $\mathrm{P}<0.05$. $\mathrm{N}=3$.

\begin{tabular}{lllllllll}
\hline & \multicolumn{2}{l}{ Melting enthalpy } & \multicolumn{2}{l}{ Onset temperature } & \multicolumn{2}{l}{ Peak temperature } & \multicolumn{2}{l}{ Range temperature } \\
& \multicolumn{2}{l}{$\Delta \mathrm{H}(\mathrm{J} / \mathrm{g})$} & $\mathrm{T}\left({ }^{\circ} \mathrm{C}\right)$ & & \multicolumn{2}{c}{$\mathrm{T}_{\mathrm{P}}\left({ }^{\circ} \mathrm{C}\right)$} & & \multicolumn{2}{c}{$\Delta \mathrm{T}\left({ }^{\circ} \mathrm{C}\right)$} \\
\cline { 2 - 9 } & $\mathrm{M}$ & $\mathrm{SD}$ & $\mathrm{M}$ & $\mathrm{SD}$ & $\mathrm{M}$ & $\mathrm{SD}$ & $\mathrm{M}$ & $\mathrm{SD}$ \\
\hline F1 & n.d. & n.d. & n.d. & n.d. & n.d. & n.d. & n.d. & n.d. \\
F2 & 1.62 & $0.42^{\mathrm{a}}$ & 104.2 & $0.99^{\mathrm{ab}}$ & 112 & $1.56^{\mathrm{a}}$ & 12.65 & $0.07^{\mathrm{ab}}$ \\
F3 & 2.26 & $1.49^{\mathrm{a}}$ & 95.83 & $4.61^{\mathrm{b}}$ & 108.7 & $1.28^{\mathrm{a}}$ & 17.33 & $4.3^{\mathrm{a}}$ \\
F2:F1(25) & 0.41 & $0.29^{\mathrm{a}}$ & 105.65 & $0.81^{\mathrm{a}}$ & 109.18 & $1.27^{\mathrm{a}}$ & 6.62 & $0.71^{\mathrm{b}}$ \\
F2:F1(50) & 0.9 & $0.36^{\mathrm{a}}$ & 101.89 & $1.69^{\mathrm{ab}}$ & 109.03 & $0.89^{\mathrm{a}}$ & 11.42 & $1.38^{\mathrm{ab}}$ \\
\hline
\end{tabular}

Liquid phase. Thermal transitions in the liquid phase would mainly be expected to be caused by the soluble components. A base line shift at around $45{ }^{\circ} \mathrm{C}$ was found for all flours, could be related to globulins and albumins (Fig 6), known to occur around $50{ }^{\circ} \mathrm{C}[25]$. A second baseline shift, caused by higher order components was found around $90{ }^{\circ} \mathrm{C}$.

Gel phase. Unlike doughs, which had different temperatures related to specific transitions, the thermal behaviour of gel phase was characterized by presenting small transitions without characteristic temperatures, hardly possible to distinguish from the noise. There were, however, two baseline shifts at $32{ }^{\circ} \mathrm{C}$ and $42{ }^{\circ} \mathrm{C}$, which were observed for all samples. Although F2 had a small peak at $68{ }^{\circ} \mathrm{C}$, no characteristic endothermic peak of the starch gelatinization was observed, more than slight shifts in the baseline that could be related to the presence of starch. These results show that ultracentrifugation produced a good separation between starch and gel phase, which is expected to be composed mainly of non-soluble pentosans. Finally around $90{ }^{\circ} \mathrm{C}$, an additional baseline shift was observed for the gel phase of F1, and specially F2. The thermal behaviour of gel reveals that this phase is thermally stable during baking.

Gluten phase. The thermal behaviour of the gluten phase was very similar for all doughs. A single endothermic peak appeared at the temperature of 73,70 and $71^{\circ} \mathrm{C}$ for samples $\mathrm{F} 1, \mathrm{~F} 2$ and $\mathrm{F} 3$ respectively. Figure $4 \mathrm{a}$ and $4 \mathrm{~b}$ show the thermal behaviour of this phase. Gluten is comprised of gliadins and glutenins. The thermal transitions of gluten proteins have been studied previously, it is generally agreed that the peaks of denaturation of these proteins are very small compared to that of other proteins, even 100 times smaller. The main endothermic peak observed in the gluten phase could be attributed to the gelatinization of the starch granules [26]. The gelatinization of the starch in gluten phases occurred at somewhat higher temperatures than in dough. This could be due to the fact that gluten is a water binder, and the enthalpy and temperature of gelatinization are very dependent on the water availability. The observation under light and polarized microscopy confirmed the presence of starch granules in the gluten phase.

The gluten phases of the blends presented a small peak (for $\mathrm{F} 2: \mathrm{F} 1(50) \mathrm{T}_{\mathrm{p}} 58.7{ }^{\circ} \mathrm{C}, \Delta \mathrm{H}=0.14 \mathrm{~J} / \mathrm{g}$, and for F2:F1(25) $\mathrm{T}_{\mathrm{p}} 59.1{ }^{\circ} \mathrm{C}, \Delta \mathrm{H}=0.11 \mathrm{~J} / \mathrm{g}$ ) previous to the broad peak (for $\mathrm{F} 2: \mathrm{F} 1(50) \mathrm{T}_{\mathrm{p}}=68.4{ }^{\circ} \mathrm{C}$, And for $\left.\mathrm{F} 2 \mathrm{~F} 1(25) \mathrm{T}_{\mathrm{p}}=70.8{ }^{\circ} \mathrm{C}\right)$. Glutenin denaturation is known to occur at around $64-80{ }^{\circ} \mathrm{C}$ since these are the 
more ordered structure proteins, followed by gliadins at $58{ }^{\circ} \mathrm{C}[25]$. The broad peaks observed in this study could be attributed to the overlapping of glutenin denaturation and starch gelatinization. Two other minor base line shifts related to amylose-lipid complexes were detected at $98.6{ }^{\circ} \mathrm{C}$ and $110{ }^{\circ} \mathrm{C}(\mathrm{F} 1)$, $99.2{ }^{\circ} \mathrm{C}$ and $114.8^{\circ} \mathrm{C}(\mathrm{F} 2)$ and $99.4{ }^{\circ} \mathrm{C}$ and $116.5^{\circ} \mathrm{C}$ (F3) (Fig. 5).

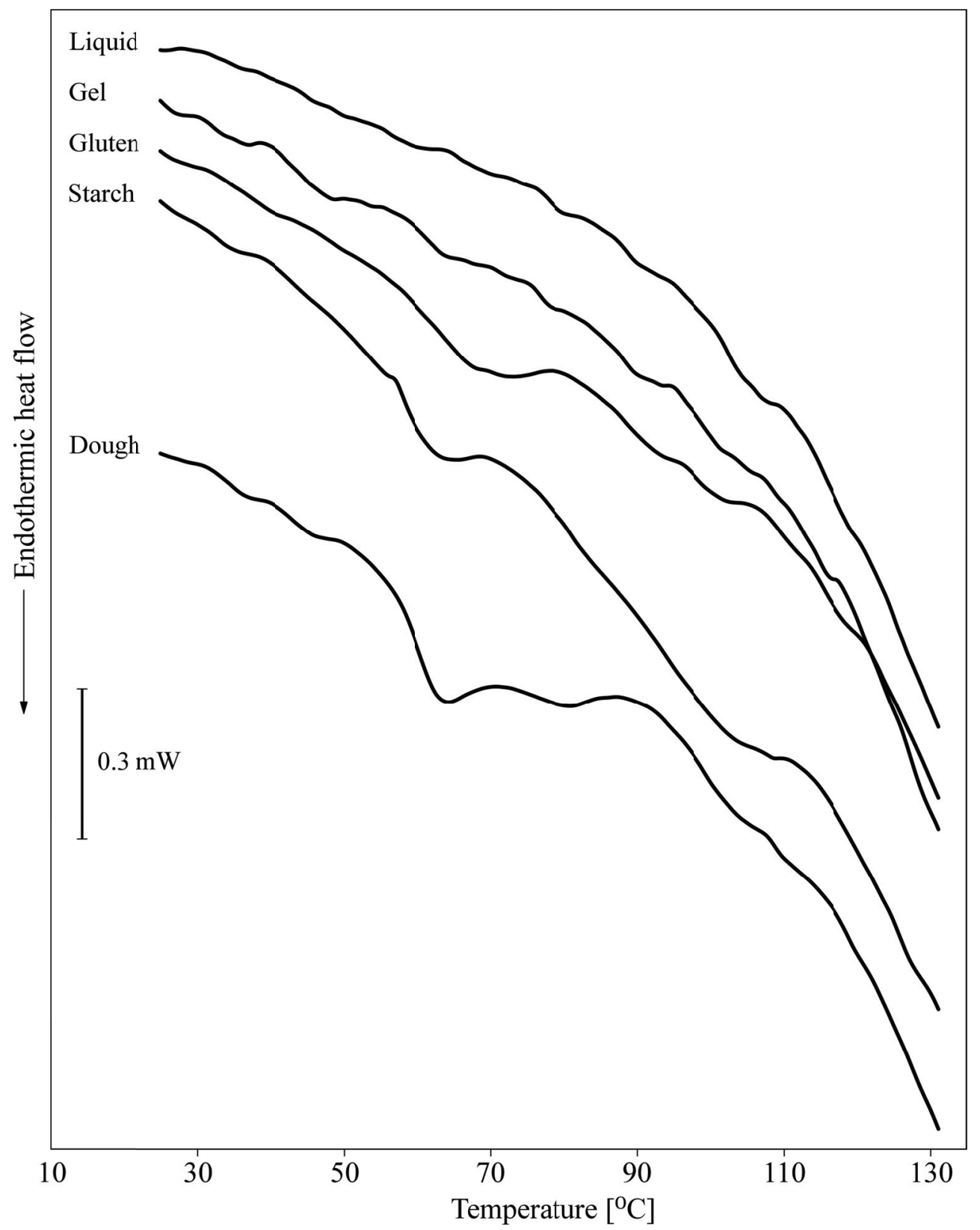

Figure 6. DSC thermograms at baking and higher temperatures of dough and its separated phases. Comparison of dough (F1) and separated liquid, gel, gluten and starch phases.

Starch phase. The starch phases had very low content and therefore the starch granules did not gelatinize. Therefore, in order to analyze starch gelatinization properties, the starch phases were diluted to $10 \%$ on dry basis. The top and bottom parts of starch phase of $\mathrm{F} 1(\Delta \mathrm{H}=8.07 \pm 0.29 \mathrm{~J} / \mathrm{g}$ and $\Delta \mathrm{H}=9.74 \pm 0.17 \mathrm{~J} / \mathrm{g})$ and $\mathrm{F} 2(\Delta \mathrm{H}=8.00 \pm 0.05 \mathrm{~J} / \mathrm{g}$ and $\Delta \mathrm{H}=7.65 \pm 0.49 \mathrm{~J} / \mathrm{g})$ presented similar starch endothermic peaks, especially for the top phase. On the other hand, F3 $(\Delta \mathrm{H}=11.85 \pm 0.58 \mathrm{~J} / \mathrm{g}$ and $\Delta \mathrm{H}=14.53 \pm 0.67 \mathrm{~J} / \mathrm{g}$ ) starch endothermic peaks were broader and more irregular. The values of $\mathrm{T}_{\mathrm{p}}$ were $60.5 \pm 0.2{ }^{\circ} \mathrm{C}$ and $60.3 \pm 0.4{ }^{\circ} \mathrm{C}$ ( $\mathrm{F} 1$ top and bottom, respectively), $62.0 \pm 0.2{ }^{\circ} \mathrm{C}$ and $61.8 \pm 0.5{ }^{\circ} \mathrm{C}(\mathrm{F} 2$, top 
and bottom), and $61.3 \pm 0.4{ }^{\circ} \mathrm{C}$ and $60.9 \pm 0.4^{\circ} \mathrm{C}(\mathrm{F} 3$, top and bottom).

As expected, the thermal transitions in the starch phase generally corresponded to the transitions of the dough [22]. The gelatinization of starch can shift to higher temperatures when less water is available, since the gelatinization of starch requires the presence of freezable water. Thermal denaturation of protein is important during the baking process. Compared to the dough, the $\mathrm{W}$ in the starch phase was lower and for the gluten phase higher. This can cause shifts in the phase transitions of separated phases compared to dough.

\section{Conclusion}

This study demonstrated that the use of ultracentrifugation coupled with DSC and microscopy allowed for the characterization of dough systems, which is relevant from a baking perspective. The study of phase separation showed direct information about the relative amount of each phase in the doughs, and that the volume fractions of liquid, gel and gluten were found to be characteristic for the different samples of flours and highly affecting flour combinations. From the microscopy analysis, the main differences between wheat flours were found in the separated gel and starch phases. The study of the water properties allowed a deeper analysis of each phase to understand how water distributes among phases, how FW differ between phases and the impact on thermal transitions in the starch phase of dough systems. It was shown that the distribution of FW in different phases had a high impact on FW in the dough, as seen especially in the starch phase of F2 dough. The gluten phase highly affected the ice melting behaviour of the dough and therefore the W and FW properties. At higher temperatures, low amounts of FW directly limited starch gelatinization. Further investigation is needed to clarify how much each phase contributes to the total gelatinization of starch, also since this interaction between components can have an effect. The methods used could be recommended as a potential tool for evaluating flours used for frozen doughs and bread product development, to understand macroscopic structure formation and thermal behaviour. Such well-defined phases could be disassembled and analysed separately at temperatures relevant for the baking process. Furthermore, the use of solvents or reagents was not necessary. To amplify this research, it would be interesting to study different wheat varieties and combinations with additional grain sources, to determine the effect of different flours with this perspective on dough structure formation and baking.

Acknowledgments. The authors gratefully acknowledge the Swedish International Development Cooperation Agency (SIDA) for their financial support.

\section{References}

1. V. Tolstoguzov, "Thermodynamic aspects of dough formation and functionality," Food Hydrocolloids, vol. 11, pp. 181-193, 1997.

2. H. Larsson and A. C. Eliasson, "Phase separation of wheat flour dough studied by ultracentrifugation and stress relaxation. I: Influence of water content," Cereal chemistry, vol. 73, pp. 18-24, 1996.

3. H. Larsson and A. C. Eliasson, "Phase separation of wheat flour dough studied by ultracentrifugation and stress relaxation. II: Influence of mixing time, ascorbic acid, and lipids," Cereal chemistry, vol. 73, pp. 25-31, 1996.

4. S. M. Loveday, V. T. Huang, D. S. Reid, and R. J. Winger, "Water dynamics in fresh and frozen yeasted dough," Critical Reviews in Food Science and Nutrition vol. 52, pp. 390-409, 2012.

5. M. B. Canalis, A. León, and P. Ribotta, "Incorporation of dietary fiber on the cookie dough. Effects on thermal properties and water availability," Food chemistry, vol. 271, pp. 309-317, 2019.

6. Y. H. Song and Q. Zheng, "Dynamic rheological properties of wheat flour dough and proteins," Trends in Food Science 85 Technology, vol. 18, pp. 132-138, 2007.

7. X. L. Ding, H. Zhang, L. Wang, H. F. Qian, X. G. Qi, and J. H. Xiao, "Effect of barley antifreeze protein on thermal properties and water state of dough during freezing and freeze-thaw cycles," Food Hydrocolloids, vol. 47, pp. $32-40,2015$

8. C. A. Stear, Handbook of breadmaking technology: Springer Science \& Business Media, 2012.

9. H. Tao, P. Wang, B. Ali, F. Wu, Z. Jin, and X. Xu, "Fractionation and reconstitution experiments provide insight into the role of wheat starch in frozen dough," Food chemistry, vol. 190, pp. 588-593, 2016. 
10. A. Bot, "Differential scanning calorimetric study on the effects of frozen storage on gluten and dough," Cereal Chemistry, vol. 80, pp. 366-370, 2003.

11. M. R. Ollivon, "Calorimetric and thermodielectrical measurements of water interactions with some food materials," in Water relationships in foods: Advances in the 1980s and trends for the 1990s., H. Levine and L. Slade, Eds., ed New York: Plenum Press, 1991, pp. 175-189.

12. C. Létang, M. Piau, and C. Verdier, "Characterization of wheat flour-water doughs. Part I: Rheometry and microstructure," Journal of Food Engineering, vol. 41, pp. 121-132, 1999.

13. T. Georgopoulos, H. Larsson, and A. C. Eliasson, "A comparison of the rheological properties of wheat flour dough and its gluten prepared by ultracentrifugation," Food Hydrocolloids, vol. 18, pp. 143-151, 2004.

14.B. J. Dobraszczyk and M. Morgenstern, "Rheology and the breadmaking process," Journal of Cereal Science, vol. 38, pp. 229-245, 2003.

15. K. Mani, C. Trägårdh, A. C. Eliasson, and L. Lindahl, "Water content, water soluble fraction, and mixing affect fundamental rheological properties of wheat flour doughs," Journal of Food Science, vol. 57, pp. 1198-1209, 1992

16. M. Raeker, C. Gaines, P. Finney, and T. Donelson, "Granule size distribution and chemical composition of starches from 12 soft wheat cultivars," Cereal Chemistry, vol. 75, pp. 721-728, 1998.

17. Z. Dai, "Starch granule size distribution in grains at different positions on the spike of wheat (Triticum aestivum L.)," Starch-Stärke, vol. 61, pp. 582-589, 2009.

18. L. Roman, E. de la Cal, M. Gómez, and M. M. Martinez, "Specific ratio of A-to B-type wheat starch granules improves the quality of gluten-free breads: Optimizing dough viscosity and pickering stabilization," Food Hydrocolloids, vol. 82, pp. 510-518, 2018.

19. V. Kontogiorgos and H. D. Goff, "Calorimetric and microstructural investigation of frozen hydrated gluten," Food Biophysics, vol. 1, pp. 202-215, 2006.

20. E. Berlin, P. Kliman, B. Anderson, and M. Pallansch, "Water binding in whey protein concentrates," Journal of Dairy Science, vol. 56, pp. 984-987, 1973.

21. M. W. Wang, R. J. Hamer, T. van Vliet, and G. Oudgenoeg, "Interaction of water extractable pentosans with gluten protein: Effect on dough properties and gluten quality," Journal of Cereal Science, vol. 36, pp. 25-37, 2002.

22. R. C. Hoseney, "Differential scanning calorimetry of starch 1 2," Journal of Food Quality, vol. 6, pp. 169-182, 1984.

23. M. Kugimiya, J. Donovan, and R. Wong, "Phase transitions of amylose-lipid complexes in starches: A calorimetric study," Starch-Stärke, vol. 32, pp. 265-270, 1980.

24. J. W. Donovan, "Phase transitions of the starch-water system," Biopolymers: Original Research on Biomolecules, vol. 18, pp. 263-275, 1979.

25. A. León, C. M. Rosell, and C. B. De Barber, "A differential scanning calorimetry study of wheat proteins," European Food Research and Technology, vol. 217, pp. 13-16, 2003.

26. A. Eliasson and P. Hegg, "Thermal-stability of wheat gluten," Cereal Chemistry, vol. 57, pp. 436-437, 1980. 